Баланюк М. В. ${ }^{[1 ;}$ ORCID ID: 0000-0001-6545-5442], здобувач вищої освіти третього (освітньо-наукового) рівня

${ }^{1}$ Національний університет водного господарства та природокористування, м. Рівне

\title{
АНАЛІЗ ДЕПОЗИТНОЇ ТА КРЕДИТНОЇ ПОЛІТИКИ КОМЕРЦІЙНИХ БАНКІВ УКРАЇНИ
}

У статті висвітлені питання ведення депозитної та кредитної політики у процесі діяльності комерційних банків України. Проаналізовано основні показники, які характеризують масштаби та об'єми коштів, а також динаміку загального фінансового результату комерційних банків. Був проведений аналіз динаміки депозитів залучених комерційними банками, а також динаміка різниці між загальним обсягом кредитів та депозитів. Також були розраховані показники динаміки темпів росту депозитів та кредитів. Запропоновані шляхи вдосконалення методів ведення депозитної політики для комерційних банків.

Ключові слова: банк; депозити; кредити; політика НБУ; грошові потоки; заощадження; фінансовий результат.

Постановка проблеми. Діяльність комерційних банків завжди перебуває в умовах солідної конкуренції на ринку та потребує удосконалення. Особливо відчутна конкуренція в тих країнах, які мають перехідну економіку, до яких належить і Україна. Саме в таких країнах завжди присутній брак вільних грошових коштів, що в свою чергу призводить до того, що громадяни, перед тим як відкрити депозитний рахунок дуже добре подумають, де і на яких умовах це вигідніше зробити.

Тому очевидним $є$ те, що депозитні ставки значно відрізняються між собою не тільки в динаміці, а й від банку до банку. Реальна дійсність підтверджує факт, що негаразди у функціонуванні кредитної системи впливають на всі економічні процеси. Саме тому надзвичайно актуальним $€$ питання щодо пошуку напрямів корегування та удосконалення [1]. Отже, дослідження у сфері депозитної та кредитної політики комерційних банків України є дуже актуальним.

Аналіз останніх публікацій. Левова частка досліджень, які стосуються депозитної та кредитної політики комерційних банків України належить таким вітчизняним та зарубіжним науковцям, як: Д. Олійник, І. Брітченко, Т. Косова, І. Ансофф, І.Балабанов, А. Єпіфанов, А. Поддєрьогін, А. Череп. 
Метою статті $€$ аналіз депозитної та кредитної політики комерційних банків України та шляхи вдосконалення методів ведення депозитної політики для комерційних банків.

Основні результати дослідження. Протягом останніх п'яти років (включно із 2018 р.) обсяги кредитів, виданих юридичним і фізичним особам збільшуються майже непомітними темпами. У 2018 році обсяг кредитів виданих фізичним особам становив 170,9 млрд грн, водночас як у 2016 р. цей показник дорівнює 157,3 млрдгрн, у відносному еквіваленті збільшення обсягів кредитування фізичних осіб становило 8,61\%.

Позитивні тенденції також спостерігаються для ринку кредитів юридичних осіб. За період з 2014 по 2018 рр. обсяг кредитів, виданих юридичним особам збільшився, адже в 2017 році сума становила вже аж 484,38 млрд грн, тоді як в 2018 р. обсяг зріс і становив вже 516,98 млрд грн, тобто зріс на 6,73\%.

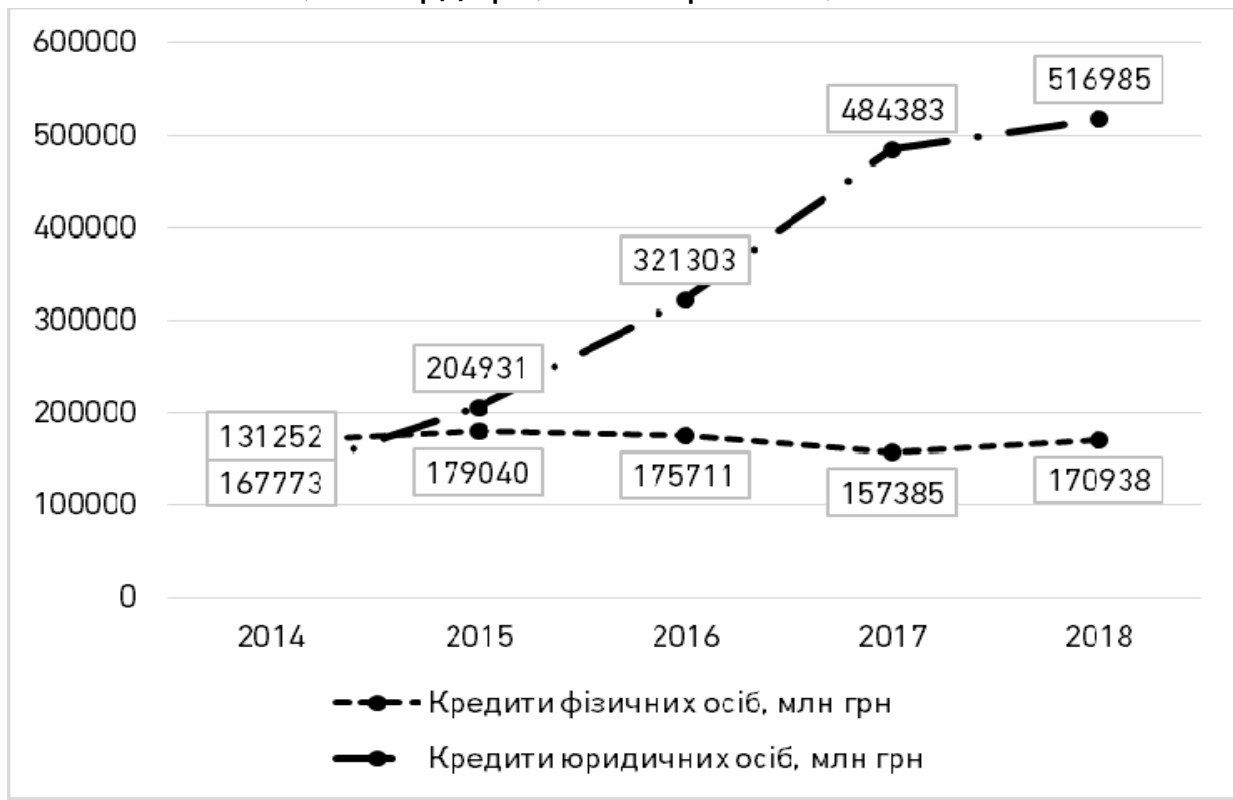

Рис. 1. Динаміка обсягів кредитів фізичних і юридичних осіб за період з 2014 по 2018 рр., млн грн

Джерело: побудовано автором на основі даних [2]

На основі рис. 1 можна підсумувати, що обсяг кредитування юридичних осіб значно перевищує обсяг кредитів виданих юридичним особам. На основі цієї тенденції можна зробити висновок про те, що кредитування відіграє вагому роль у забезпеченні розвитку бізнесу в Україні. Крім цього, можна зауважити, що у 2018 р. відбувається зростання обсягу виданих кредитів як фізичним, так і юридичним особам. Це свідчить про те, що додатково 
залучені кошти у 2018 р. були використані для покриття дефіциту капіталу на фінансовому ринку України, а також про те, що підприємницька активність продовж 2018 р. демонструє тенденцію на зростання.

3 метою визначення напрямків використання додаткового залучених коштів комерційними банками протягом досліджуваного періоду з 2014 по 2018 р., на рис. 2 приведено порівняльну динаміку абсолютної зміни загального обсягу кредитів виданих комерційними банками України та абсолютної зміни загального обсягу зобов'язань за період з 2014 по 2018 р.

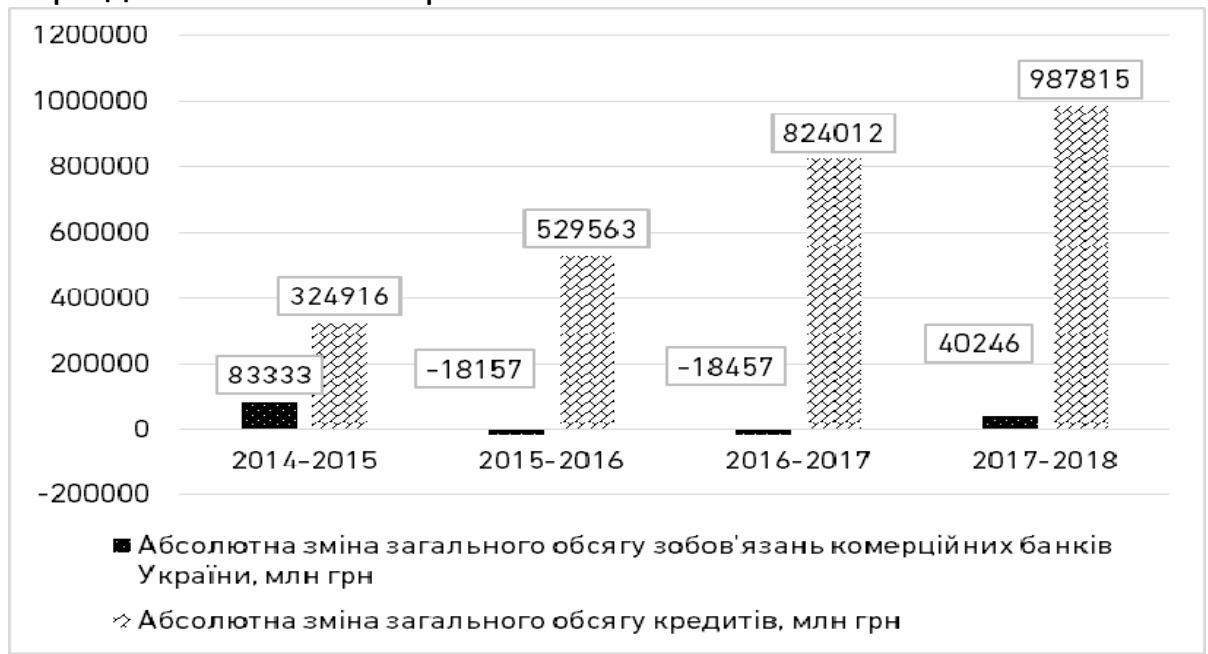

Рис. 2. Порівняльна динаміка абсолютної зміни загального обсягу кредитів та зобов'язань за період з 2014 по 2018 рр., млн грн Джерело: побудовано автором на основі даних [2]

Як бачимо з рис. 2, динаміка абсолютної зміни обсягу зобов'язань та загального обсягу кредитів $€$ корельованою протягом періоду з 2014 по 2018 р., що свідчить про те, що значна частка додаткового залучених коштів була спрямована на видачу кредитів юридичним і фізичним особам, які за досліджуваний період зросли (див. рис. 1). Вагомим фактором успішності підприємництва у банківському секторі $\epsilon$ ситуації на ринку депозитів. Таким чином, депозитна політика банку $є$ складовою частиною банківської стратегії, яку реалізують через механізм фінансового менеджменту банку [3, С. 4]. Це пов'язано з тим, що залучення коштів дозволяє розширювати обсяги кредитування та збільшувати фінансовий результат. Тому аналіз динаміки обсягів кредитування не $\epsilon$ повним, якщо опустити дослідження динаміки обсягу депозитів. 3 цією метою на рис. 3 приведено обсяги депозитів, залучених від юридичних та фізичних осіб комерційними банками України за період з 2014-2018 рр. 


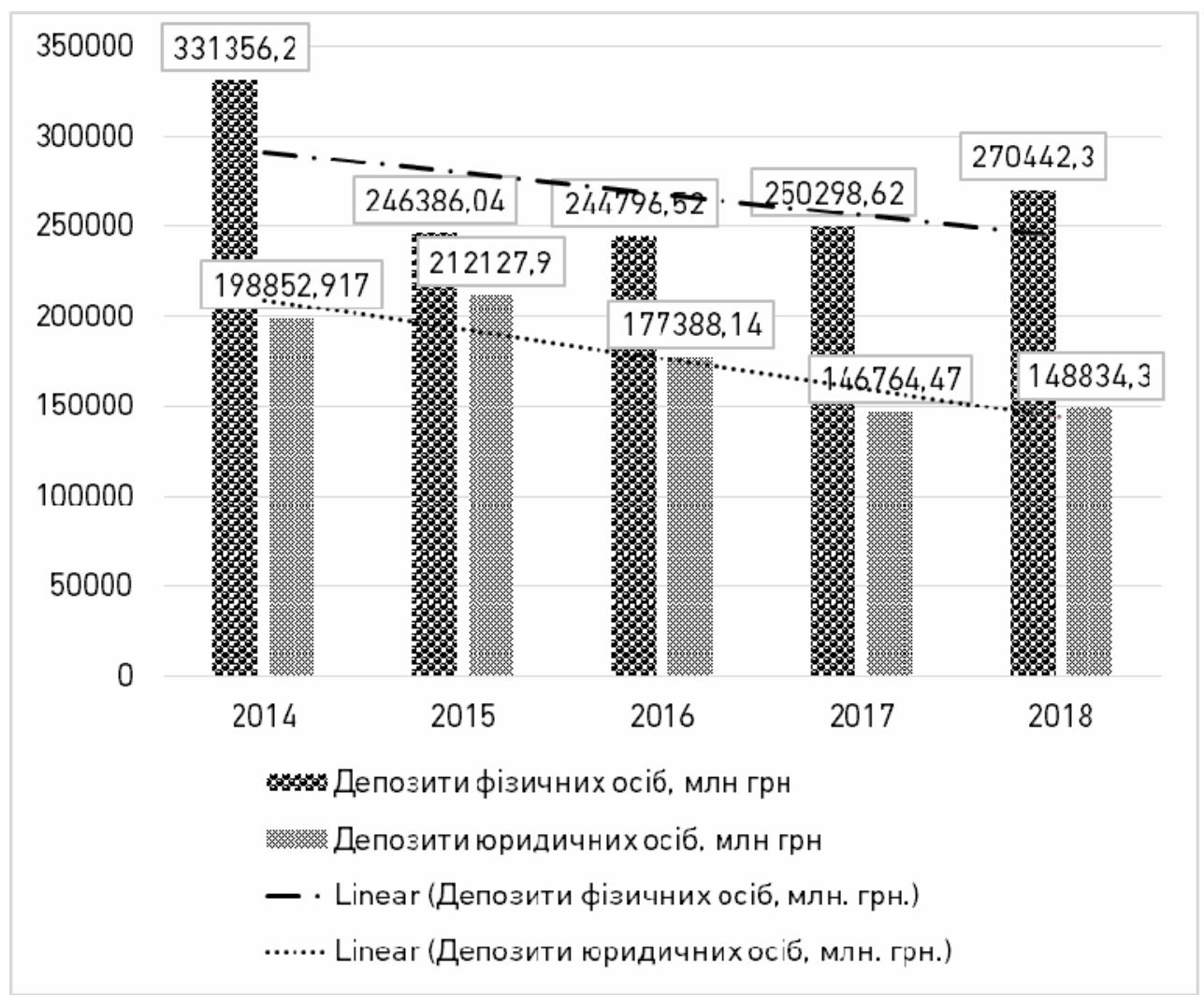

Рис. 3. Динаміка депозитів, залучених комерційними банками України за період 2014 по 2018 рр., млн грн

Джерело: побудовано автором на основі даних [2]

На основі детального аналізу рис. 3 підсумуємо, що динаміка депозитів протягом досліджуваного періоду $\epsilon$ спадаючою, проте у 2017 р. та у 2018 р. темпи відтоку депозитів фізичних осіб дещо зросли. Під депозитною політикою у вузькому значенні розуміють стратегію і тактику банку в частині організації депозитного процесу з метою забезпечення його ліквідності [4, С. 98]. Більше того у 2018 р. спостерігається зростання обсягу депозитів, одержаних вітчизняними комерційними банками від юридичних, а не тільки від фізичних осіб. Хоча протягом досліджуваного періоду загальний обсяг депозитів скоротився на 110,9 млрд грн або на $26,45 \%$, у 2018 порівняно із кінцем 2017 р. спостерігається зростання цього показника на 22,21 млрд грн або на 5,59\%. Це дає підстави вважати уповільнення відтоку депозитів із банківської системи України та наявність перших «симптомів» ії відновлення. 
Виходячи із загальної мети комерційного банку, визначають пріоритетні напрями його депозитної політики 3 позиції прибутковості, рентабельності, ліквідності, мінімізації ризиків, оптимізації депозитного портфеля [5]. Вітчизняні банки застосовують такі види процентів, як прості, складні, прогресивно зростаючі, а також виплата відсотків наперед [6, С. 187].

Головними причинами зростання обсягу депозитів можна вважати стабілізацію гривні, високі ставки (16-20\% річних) та націоналізацію ПриватБанку, що призвело до зростання частки державних банків на ринку банківських послуг (55\%), що в свою чергу підсилило довіру населення до національної банківської системи. Основним напрямом розвитку банківського дистанційного обслуговування клієнтів у майбутньому стануть такі канали просування банківських послуг, як маркетинг через Інтернет, інтерактивні філії [7]. Варто зазначити, що якщо юридичні особи беруть значно більше кредитів ніж фізичні особи, то на противагу цьому результату, вітчизняні комерційні банки залучають значно більше депозитів від фізичних осіб, а не від юридичних. Це зумовлено тим, що юридичні особи схильні використовувати вільні кошти для інвестицій у бізнес, а не для збережень на депонованих рахунках у банках.

3 метою деталізації отриманих результатів необхідним $\epsilon$ дослідження різниці між депозитами та кредитами, оскільки джерелом кредитів часто виступають саме кошти, отримані як депозити. Для цього на рис. 4 приведено динаміку різниці між загальними значеннями обсягів кредитів та депозитів за період 3 2014 по 2018 p.

На основі динаміки різниці між кредитами і депозитами за період з 2014 по 2018 р. можна підсумувати, що помітний тренд на скорочення цього показника, що дає підстави припускати, про збільшення частки депонованих коштів у кредитному портфелі банків. Проте для більш глибокого аналізу необхідним дослідити надійність цього портфелю, що дасть змогу визначити рівень надійності депозитів. 


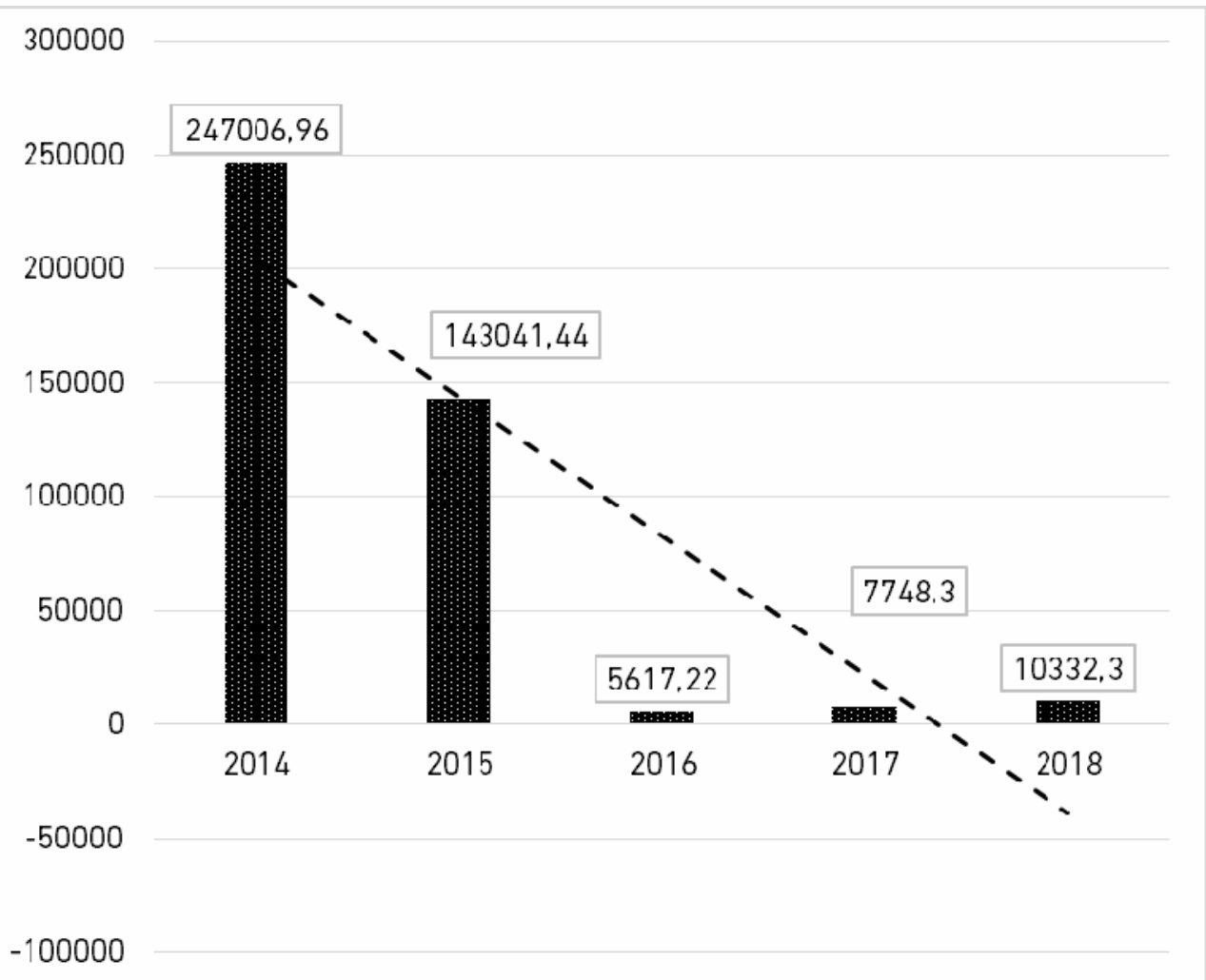

Рис. 4. Динаміка різниці між загальним обсягом кредитів та депозитів за період з 2014 по 2018 рр., млн грн

Джерело: побудовано автором на основі даних [2]

На рис. 5 відображено порівняльну динаміку темпів росту кредитів та депозитів за період з 2014 по 2018 р.

Як бачимо з рис. 5, динаміка депозитів та кредитів є взаємнокорельованою та не відрізняється яскравими екстремумами, що свідчить про явне початок відновлення банківської системи з 2016 р. та його продовження продовж усього досліджуваного періоду. Висока кореляція між досліджуваними параметрами дає змогу припустити, що комерційні банки залучені депоновані кошти інвестують в економіку у формі кредитів.

Дослідження динаміки загального фінансового результату комерційних банків України показало, що його динаміка була вкрай нестабільною та в загальному негативною. Проте у 2017 р. значення даного показника зросло і вперше за останні три роки є додатнім. Більш детально динаміка значень загального фінансового результату комерційних банків приведена на рис. 6. 


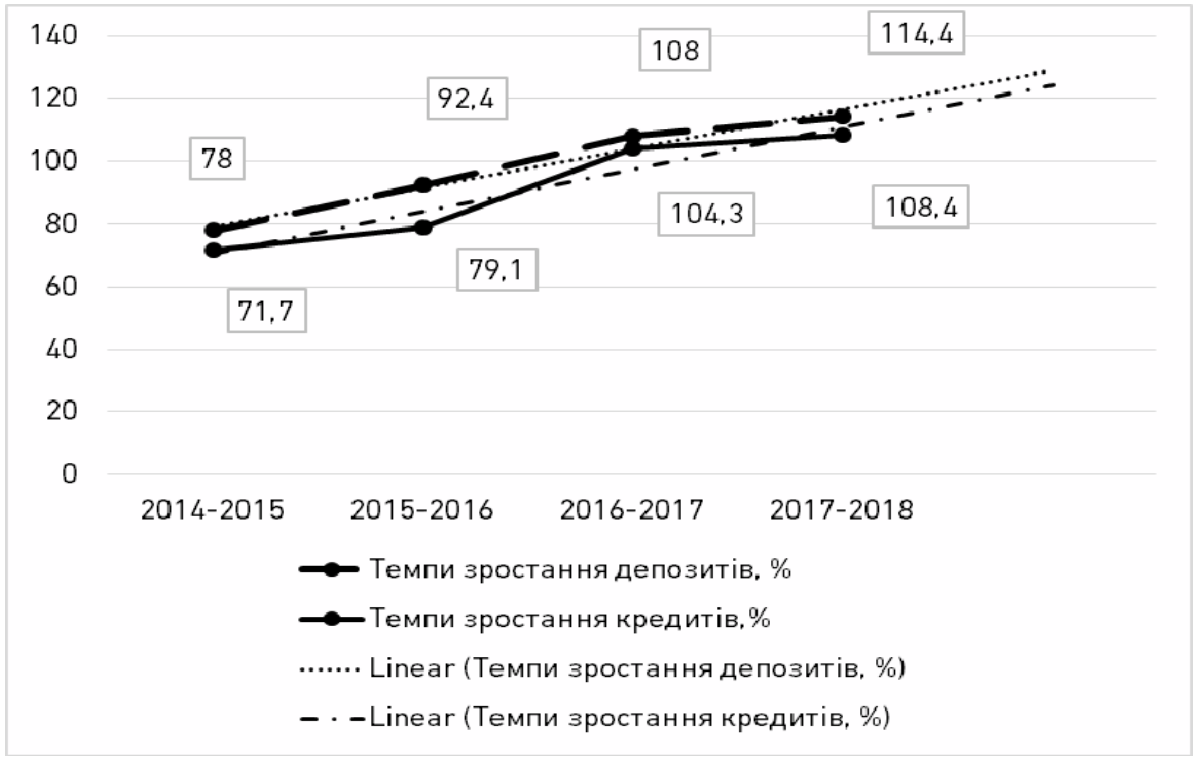

Рис. 5. Динаміка росту депозитів та кредитів за період з 2014 по 2018 рр., \%

Джерело: побудовано автором на основі даних [2]

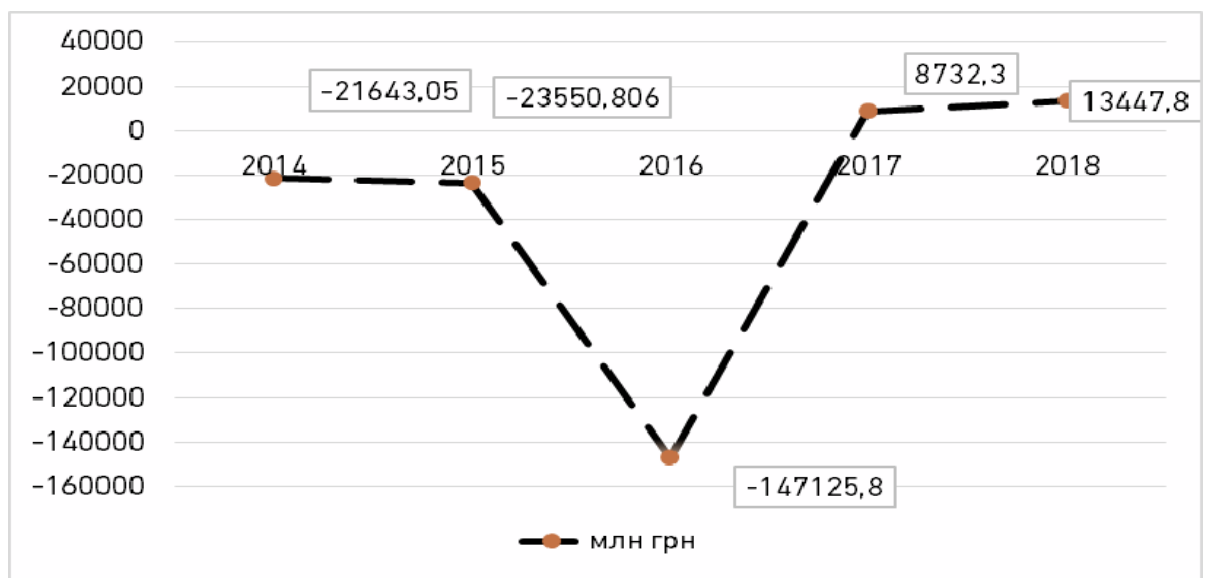

Рис. 6. Динаміка загального фінансового результату

комерційних банків України за період з 2014 по 2018 рр., млн грн

Джерело: побудовано автором на основі даних [2], під загальним фінансовим результатом розуміється сума значень даного показника для всіх комерційних банків України

Як бачимо з рис. 6, за останні 5 років значення фінансового результату $є$ найкращим станом на кінець 2018 р. Це у порівнянні із динамікою активів, їх структури та депозитів і кредитів свідчить про відновлення національної банківської системи України після кризи. Найменше значення загального фінансового результату спостерігалось у 2016 р. і становило $(-147,12)$ млрд грн.

Таким чином, можна відзначити, що вітчизняна банківська 
система за період з 2014 по 2016 р. загалом знаходилась у стані занепаду, проте за останні два роки, тобто 2017-2018 рр., помітні «перші симптоми» їі відновлення.

Висновки. Отже, провівши аналіз депозитної та кредитної політики комерційних банків України, можемо сказати, що всупереч прогнозів люди почали більше довіряти банкам та користуються їх послугами все більше. Проте для того, щоб ця тенденція залишалась позитивною варто удосконалювати наявні системи захисту коштів фізичних і включення до неї вкладів від юридичних осіб та фізичних осіб-підприємців. Це дасть додаткову можливість вкладникам бути більш впевненими в тому, що всі умови договору будуть виконуватись на $100 \%$ і регулятор (у нашому випадку НБУ) не буде мати такого колосального впливу на цей процес, використовуючи свої заборони і рекомендації. Ряд цих кроків створить цілковито нову систему відносин між банком і клієнтом та зможе забезпечувати функціонування банку дійсно на незалежних засадах.

1. КожельН. Основні тенденції змін у структурі вкладів на українському депозитному ринку як свідчення зміцнення довіри до банків. Вісник НБУ. 2004. 48 с. 2. Офіційний сайт Національного банку України. URL: http://www.bank.gov.ua. (дата звернення: 22.06.2020). 3. Андрушків Т. Депозитна політика комерційного банку та напрями її вдосконалення. Українська наука: минуле сучасне, майбутнє. 2012. 13 с. 4. Бартош О. Депозитна політика банку та основні етапи ії формування. Вісник УБС НБУ. 2008. С. 97-101. 5. Смоляк В. А., Світлична О. І. Сутність депозитної політики банків. URL: http://www.rusnauka.com/ (дата звернення: 23.06.2020). 6. Лавров Р. В. Депозитна політика банку в сучасних умовах. Науковий вісник ЧДІЕУ. 2010. С. 182-187. 7. Тертична Н. В. Удосконалення механізму формування депозитної політики в банках України. Науковий вісник ЛНАУ. 2009. С. 141-147.

\section{REFERENCES:}

1. Kozhel N. Osnovni tendentsii zmin u strukturi vkladiv na ukrainskomu depozytnomu rynku yak svidchennia zmitsnennia doviry do bankiv. Visnyk NBU. 2004. 48 s. 2. Ofitsiinyi sait Natsionalnoho banku Ukrainy. URL: http://www.bank.gov.ua. (data zvernennia: 22.06.2020). 3. Andrushkiv T. Depozytna polityka komertsiinoho banku ta napriamy yii vdoskonalennia. Ukrainska nauka: mynule suchasne, maibutnie. $2012.13 \mathrm{~s}$. 4. Bartosh 0 . Depozytna polityka banku ta osnovni etapy yii formuvannia. Visnyk UBS NBU. 2008. S. 97-101. 5. Smoliak V. A., Svitlychna O. I. Sutnist depozytnoi polityky bankiv. URL: http://www.rusnauka.com/ (data zvernennia: 23.06.2020). 6. Lavrov R. V. Depozytna polityka banku v suchasnykh umovakh. Naukovyi visnyk ChDIEU. 2010. S 182-187. 7. Tertychna N. V. Udoskonalennia mekhanizmu formuvannia depozytnoi polityky v bankakh Ukrainy. Naukovyi visnyk LNAU. 2009. S. 141-147. 


\section{ANALYSIS OF DEPOSIT AND CREDIT POLICY OF COMMERCIAL BANKS IN UKRAINE}

The article covers the issues of Deposit and credit policy in the course of the activities of commercial banks in Ukraine. The main indicators that characterize the scale and volume of funds, as well as the dynamics of the overall financial result of commercial banks, are analyzed. We analyzed the dynamics of deposits attracted by commercial banks, as well as the dynamics of the difference between the total volume of loans and deposits. The essence and principles of the Bank's Deposit policy formation are studied. External and internal factors of influence on the Deposit policy are determined. The stages of formation of the Deposit policy, the main issues and the decision to accept it and solve possible problems. The main financial result for the end of 2018 is considered.

The essence and features of the formation and implementation of the credit policy of a commercial Bank are considered. The structure and dynamics of loans provided by banks in the post-crisis period are analyzed. The problems encountered in the lending process are identified and their impact on the development of the Ukrainian economy is proved.

The place and role of Deposit and credit policy of a commercial Bank in ensuring the effectiveness of the banking system is considered. Generalized tools for implementing the Deposit policy of a commercial Bank. Measures for improvement and development are proposed deposit policy of banks. In modern conditions for the development of the Ukrainian economy implementation of effective credit policy strategies of commercial banks it will help to strengthen the banking sector in order to consolidate the economic stability of the state.

We also calculated the dynamics of growth rates of deposits and loans. Ways to improve methods of conducting deposit policy of commercial banks are suggested.

Keywords: bank; deposits; loans; NBU policy; cash flows; savings; financial result. 
Баланюк М. В. [1; ORCID ID: 0000-0001-6545-5442], соискатель высшего образования третьего (образовательнонаучного уровня

'Национальный университет водного хозяйства и природопользования, г. Ровно

\section{АНАЛИЗ ДЕПОЗИТНОЙ И КРЕДИТНОЙ ПОЛИТИКИ КОММЕРЧЕСКИХ БАНКОВ УКРАИНЫ}

В статье освещены вопросы ведения депозитной и кредитной политики в процессе деятельности коммерческих банков Украины. Проанализированы основные показатели, которые характеризуют масштабы и объемы средств, а также динамику общего финансового результата коммерческих банков. Был проведен анализ динамики депозитов, привлеченных коммерческими банками, а также динамика разницы между общим объемом кредитов и депозитов. Также были рассчитаны показатели динамики темпов роста депозитов и кредитов. Предложены пути совершенствования методов ведения депозитной политики коммерческих банков.

Ключевые слова: банк; депозиты; кредиты; политика НБУ; денежные потоки; сбережения; финансовый результат.

Стаття надійшла до редакції 01.04.2020 р. 